\title{
Petrochemistry of Two Magnetite Bearing Systems in the Precambrian Belt of Southern Cameroon
}

\author{
Gilles Nyuyki Ngoran1,2*, Cheo Emmanuel Suh', Dunkan Bowker, Raymond Beri Verla², \\ Godlove Tasin Bafon ${ }^{4}$ \\ ${ }^{1}$ Ministry of Mines, Industry and Technological Development, Yaounde, Cameroon \\ ${ }^{2}$ Explorers 33 Consulting Group, Yaounde, Cameroon \\ ${ }^{3}$ Economic Geology Unit, Department of Geology, University of Buea, Buea, Cameroon \\ ${ }^{4}$ West African Minerals Cooperation, Compagnie Minière du Cameroon, Yaoundé, Cameroon \\ Email: *gillesngoran@gmail.com
}

Received 28 February 2016; accepted 18 April 2016; published 21 April 2016

Copyright (C) 2016 by authors and Scientific Research Publishing Inc.

This work is licensed under the Creative Commons Attribution International License (CC BY). http://creativecommons.org/licenses/by/4.0/

(c) (i) Open Access

\section{Abstract}

In the past decades, several iron ore occurrences have been discovered in the Precambrian Belt of southern Cameroon, with focus on their economic potential, and little attention on the deposit type. However, few studies have been geared towards understanding the different deposit types within this region. This paper seeks to provide new insight on the different styles of iron ore mineralisation of two potential, yet least studied iron ore deposits in this region in addition to enhancing exploration efforts within the different prospects. Petrology and geochemistry of rock samples from the Binga and Djadom iron prospects in southern Cameroon are investigated. The structural disposition of the prospects was mapped and cores described, sampled and subsequently analysed to enhance the understanding of the alteration mineralogy, ore mineralogy and textural features of the iron-bearing lithologies. Polished thin sections were studied by standard microscopy while the bulk rock geochemistry was determined by X-ray fluorescence (XRF) for major and trace elements. At Binga, the main rock types are magnetite gneisses, amphibolites, quartz-biotite gneisses, and mafic intrusions, while the main rocks encountered at Djadom are magnetite gneisses, amphibolitic BIFs, quartz-biotite gneisses, amphibolites and fault rocks. At both prospects, the target lithology for iron ore is the magnetite gneiss. The magnetite gneisses at the Binga prospect are weakly to moderately foliated, but strongly foliated at Djadom, and both contain fractures that are healed by irregular magnetite. Magnetite is anhedral to euhedral in outline and it is closely associated with amphibole, garnet and pyroxene. Iron content of the magnetite gneisses ranges from $17.44-33.40 \mathrm{wt} \%$ (at Binga) and $27.73-43.39 \mathrm{wt} \%$ (at Djadom) and the ore enrichment process involved progressive loss of silica and aluminium. Trace element concentrations show high contents of $\mathrm{Ba}, \mathrm{Zn}, \mathrm{Cu}$ and $\mathrm{V}$ but lower abundances of $\mathrm{Sr}$ and $\mathrm{Zr}$, as well as low

\footnotetext{
*Corresponding author.
} 
values for $\mathrm{Ti}$ in both prospects. At the Binga iron ore prospect, $\mathrm{TiO}_{2}$ and $\mathrm{Al}_{2} \mathrm{O}_{3}$ display a linear co-variation with $\mathrm{Zr}$, while in the Djadom prospect, $\mathrm{TiO}_{2}, \mathrm{Al}_{2} \mathrm{O}_{3}$ and $\mathrm{MgO}$ display a negative co-variation with $\mathrm{Zr}$. The origin of the former could be linked to a magmatic fluid-related process, while the genesis of the later is tied to both skarn formation and hydrothermal enrichment.

\section{Keywords}

Magnetite Gneiss, Amphibolitic BIF, Skarn, Hydrothermal Enrichment

\section{Introduction}

With the high demand for steel worldwide, partly driven as a result of global economic growth, exploration for new iron deposits is experiencing a boom, particularly in nonproducing countries such as Cameroon [1]. The principal iron formations in the world were deposited during the Late Archean to the Paleoproterozoic and less significant deposits in the Neoproterozoic [2]. Deposits of these different ages are represented in Cameroon, and were discovered between the early 1960's to the late 1990's by bilateral co-operation agreements between the government and international organizations such as Bureau de Recherche Géologique et Minière (BRGM) and United Nations Development Program [3]. These iron ore occurrences include the; Mbalam, Mamelles, Nkout, Ngovayang and Mewongo prospects (Archean to Paleoproterozoic in age) and Mayo-Binka (Proterozoic), which over the years have formed the focus of iron ore exploration activities in Cameroon [4]. Several studies have been carried on the Precambrian Mineral Belt of southern Cameroon, by scientist in the mining industry leading to the discovery of some deposits. All those works for the most part were very globalizing ignoring the style of iron ore mineralization. However, many of these works are unpublished because of the known confidentiality characterizing the mining domain. Moreover, little attention has been focused on other iron ore occurrences in the country.

According to [1], two styles of iron ore mineralization are recognized in the Precambrian mineral belt of Cameroon; an example of type 1 is the Mayo Binka, which consist of magnetite vein related to mylonitized and silicified granitoid-hosted shear zones probable of Pan-African such as the; and type 2 itabirite-hosted iron deposits of Archean and early Proterozoic age such as the Metzimevin and Mbalam deposits.

This study seeks to provide new insight on iron ore mineralization within the Precambrian Belt of southern Cameroon (northern extension of the Congo Craton) and contribute to exploration efforts of Compagnie Minière $d u$ Cameroun, currently exploring for iron ore in this region.

\section{Geographic and Geologic Context of the Djadom and Binga Iron Ore Prospects}

The Djadom and Binga iron ore prospects are located in southern Cameroon, at the northern edge of the Congo craton (Figure 1) near the frontier with the Republic of Congo. Djadom lies between latitude (UTM easting) 24,500 and 24,900 and longitude (UTM northing) 38,200 and 38,600, while Binga lies latitude (UTM easting) 687,442 and 673,186 and longitude (UTM northing) 273,930 and 265,438. This region is situated in the equatorial forest belt and is characterized by a humid equatorial climate, without defined wet and dry seasons. There is a long dry season from December to May, followed by a light wet season in the months of May and June, then a short dry season from July to October and a heavy wet season from October to November. The annual rainfall in this region ranges from between 150 and $220 \mathrm{~cm}$ per year. The topography in the region is highly undulating, with a local drainage that is well developed [5] [6].

The Ntem Complex constitutes the Archean cratonic basement of southern Cameroon and lies at the north western coner of the Congo Craton in central Africa [7]. This complex is divided into two main structural units, namely the Ntem Unit (which host the Binga Prospect) and the Nyong Series (which host the Djadom Prospect). The Ntem unit is $>2900$ Ma old consists mainly of quartzites, amphibolites, schists, and gneisses, reminiscent of sediments once laid down in a geosynclinal basin [8].

The Paleoproterozoic Nyong Series is defined as the reactivated NW corner of the Archean Congo craton [9], [10] and is characterized by; migmatitic orthogneisses, felsic gneisses of volcanic to volcano-sedimentary origin, quartzites, and banded iron formations [11]. Both units are distinguished on the basis of different petrological, structural and geochronological features [11]-[14]. 


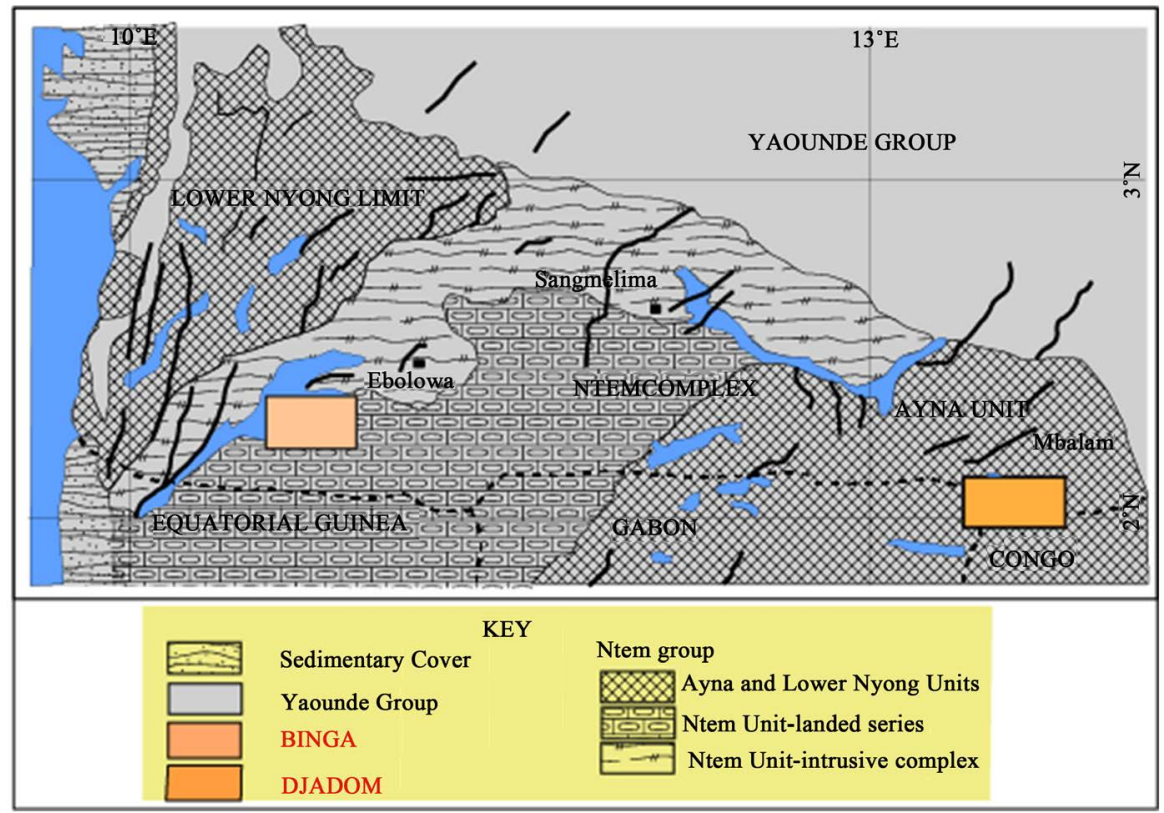

Figure 1. Regional geological map of the northern limit of the Archaean Congo Craton (Ntem complex, the Nyong Unit) showing the location of the Binga and Djadom iron ore prospects. Modified after [12]. NB: Map is not drawn to scale.

\section{Location of the Binga and Djadom Iron Ore Prospects}

The Binga and Djadom iron ore prospects are located in the Precambrian Belt of southern Cameroon, and form part of what is locally termed the Central African Iron Ore Emerging Province, which is known to host several world class deposits, such as; Mballam, Nkout, Ntem, Ngovayang and the Mamelles in southern Cameroon, and Boka Boka, Belinga, Badongo, Nabeba, Minkebe, Avima, in Congo and Gabon.

\section{Sampling and Analytical Procedures}

\subsection{Core Sampling}

Core samples for this study were collected from six different diamond drill holes, three from each iron ore prospect. The core samples were carefully selected to represent the span of possible Fe-rich chemistry within both prospects, also taking into consideration the distance between drilled holes (holes that were selected were widely spaced) and drill depth which was on average 100 meters. These cores comprise mainly of magnetite gneisses, amphibolitic BIFs, amphibolites, mafic intrusions and fault rocks (dominated quartz with stains of goethite). Samples BCS08, BCS09, BCS013, were selected for Binga and DCS04, DCS05, and DCS020 for Djadom (Figure 2 and Figure 3) represent the targets from which these samples were collected for this study.

Only fresh samples were selected for this study, as thin sections could not be prepared on weathered samples. The author was part of the drilling team and after. The cores obtained were laid out in numbered sample boxes, and after determination of the sample depth the cores were subsequently quartered using a diamond saw (Figure 4).

The core samples, once selected were carefully described and placed in pre-labelled samples bags.

\subsection{Sample Preparation Prior to Shipment for Analysis}

After sampling, the cores were sent to Alex Steward (ALS) laboratory facility in Mvan Yaoundé, where they were dried in an electric oven at a temperature of about $1200^{\circ} \mathrm{C}$ or more, depending on their moisture content. This makes the samples friable so as to ease to the subsequent procedures.

Next the dried samples were then crushed to fractions of about $2 \mathrm{~mm}$ using a jaw crusher. This reduced the bulk sample into mille-able sizes, which was then introduced directly into the milling bowl. The main objective of milling the sample is to increase the surface area of the sample, thus exposing the target minerals for reaction with reagents during subsequent chemical attack. After milling, the samples were split into sub samples using a riffle splitter, thus homogenizing the samples into representative sub-samples. 


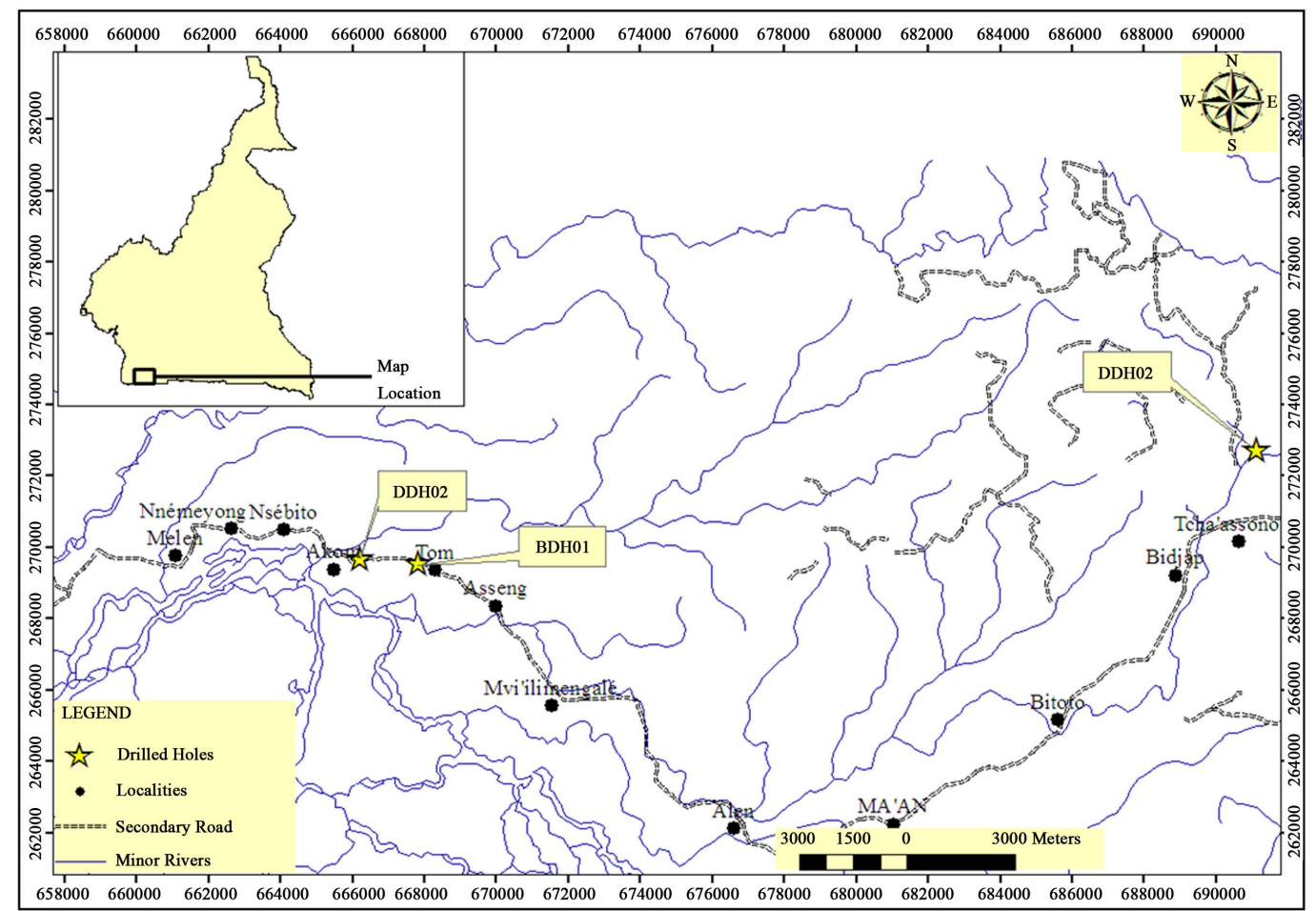

Figure 2. Drainage map of Kribi (southern Cameroon), with a dendredic parttern within the Binga iron ore prospect. The yellow stars represent drill points from which samples for this studies were collected, while the black lines represent the secondary roads within the prospect area.

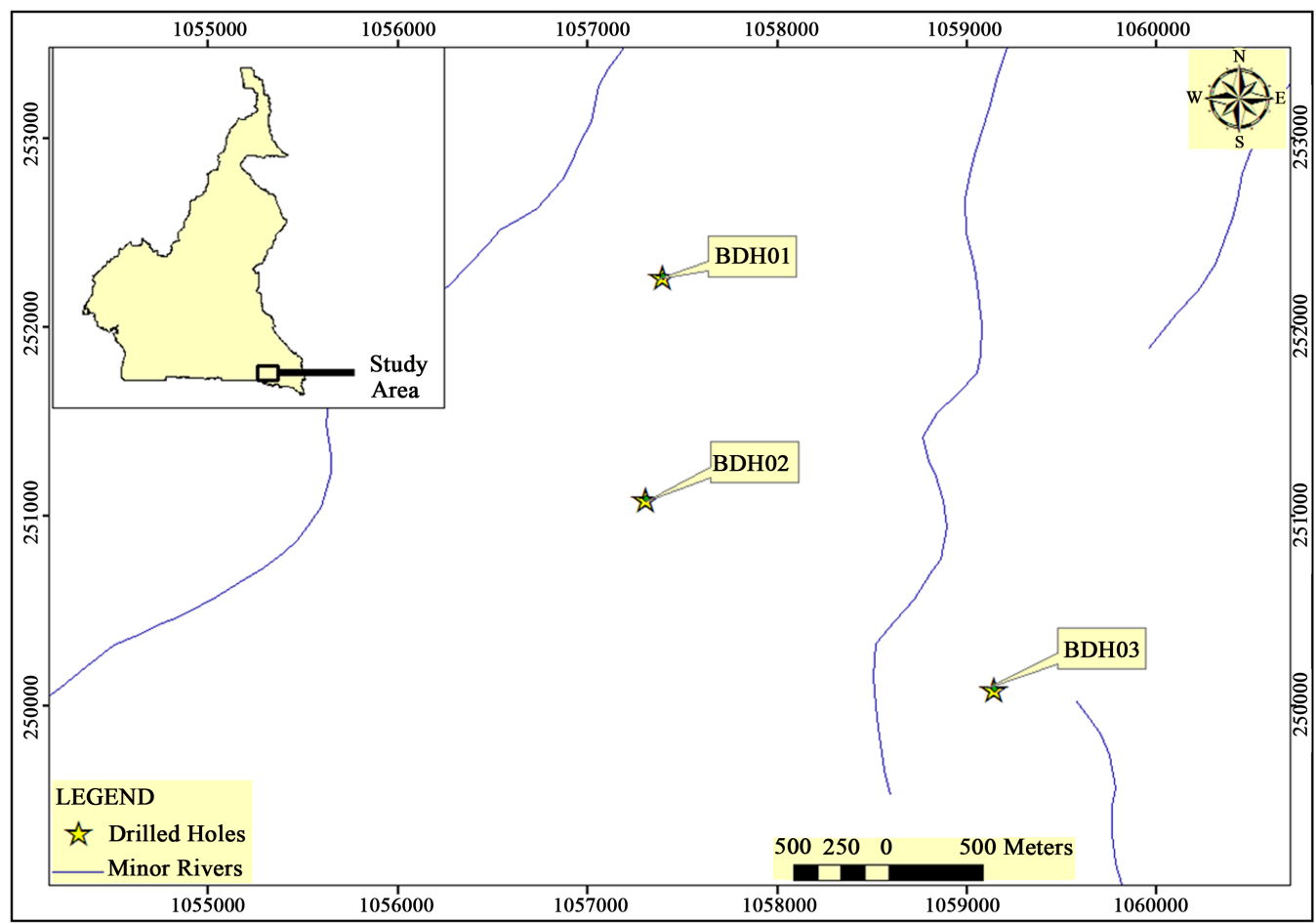

Figure 3. Drainage map of Ngoila (south eastern Cameroon), showing an almost north-south (which is corncordanrt with the regional foliation in the country) drainage pattern within the Binga iron ore prospect. The yellow stars represent drill points from which samples for these studies were collected within the prospect area. 


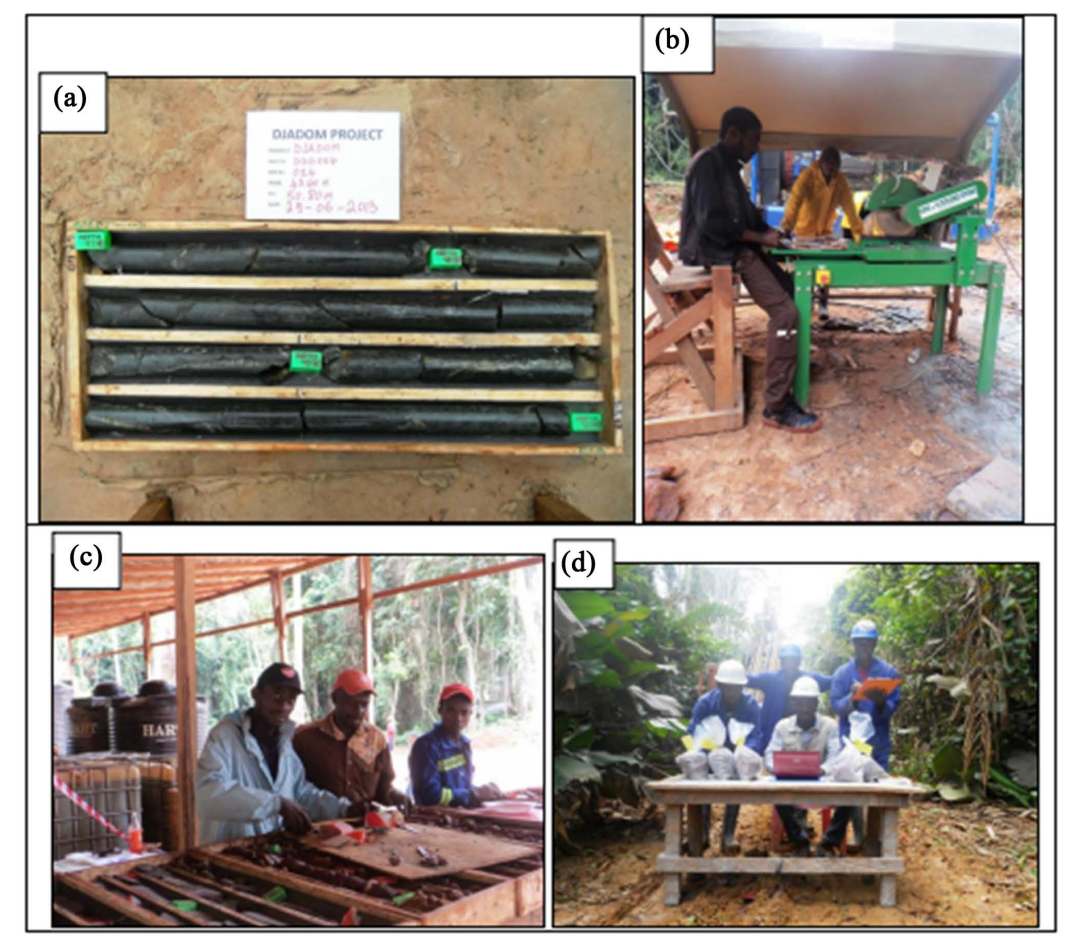

Figure 4. (a) Laid out core samples from Djadom (b) cutting core samples using a diamond saw (c) sampling of pre-selected core samples for analysis (d) labeling and weighing of selected core samples.

This overall exercise also reduces the weight, while preserving the homogeneity of the sample thereby reducing the cost incurred for shipment.

\subsection{Laboratory Methods}

The milled samples were shipped to the ALS laboratory in Cape Town South Africa, where they were analyzed for major and trace elements by use of X-Ray Florescence (XRF) technique after lithium metaborate fusion. The advantage of this method is that there is relatively low flux to sample ratio, which offers good sensitivity for the majority of elements and creates a matrix which is not subject to particle size effect.

With very low spectral interferences and high instrument sensibility, the XRF method delivers highly accurate and precise results across the full range of iron oxide ore types.

For more on the analytical technique please visit [15].

Subsamples of the uncrushed core material were taken to "Laboratoire de Traitement des Minerais (LTM) de Nkol-Bisson" in Yaounde, where thin sections for petrographic analysis were prepared. These were subsequently studied under an ore microscope at the Department of Geology, University of Buea.

\subsection{Data Analysis and Map Production}

Geochemical data were computed and plotted with the aid of the Geochemical Data Toolkit (GCD kit) software package, while the maps were produced by the couple use of Surfer9, and ArcGIS 10 software systems.

\section{Results}

\subsection{Petrography}

The main rock types at the Binga iron ore prospect are magnetite gneisses, amphibolites, gneisses, and mafic intrusions, while the main rocks encountered at the Djadom iron ore prospect are magnetite gneisses, amphibolitic BIFs (an intercalation of Banded Iron Formations and amphibolite), gneisses, amphibolites and fault rocks. 


\subsubsection{Petrographic Description of Samples from the Binga Iron Ore Prospect}

The magnetite gneisses at Binga (samples BD.9.50, BD.9.67, BD.9.86, BD.13.19, BD.13.28, and BD.13.38) are generally granoblastic and porphyroblastic with a dominance of magnetite over quartz and other gangue minerals. Mineralogically, they are dominated by magnetite, amphibole, quartz, garnet, and a few crystals of pyroxene and biotite. The magnetite grains are occasionally stretched defining a weak mineral lineation of magnetite stringers that accentuates the foliation in the rock (Figure 5(a)). Magnetite also occurs as anhedral inclusions in garnet and amphibole. Quartz shows a granoblastic texture forming the matrix in the rocks. The rocks at Binga are highly deformed as quartz, pyroxene, and garnet are fractured and curviplanar fractures in quartz are more conspicuous. In most cases the fractures are filled with magnetite (Figure 5(b) \& Figure 5(c)).

In the highly deformed samples, quartz exhibits wavy extinction and contains micro-fractures healed by sericite (Figure 5(c)), while plagioclase is altered resulting in vacuolization (Figure 5(d)), thus forming a lock-andkey structure.

The amphibolites in Binga are generally granoblastic (samples BD.8.50, BD.8.52, BD.8.54). Magnetite occasionally appears as an opaque core with serrated margins enclosed within altered amphibole (Figure 6(a)). Magnetite is closely associated with amphiboles, and the latter commonly occurs as green hornblende, mostly lenticular in shape (Figure 6(b) \& Figure 6 (c)).

Kyanite occurs as a lenticular crystal, with inclusions of magnetite within its matrix (Figure 7(a)), while chlorite occurs as a secondary mineral possibly resulting from the alteration of biotite (Figure 7(b)).

\subsubsection{Petrographic Description of Samples from the Djadom Iron Ore Prospect}

The Djadom magnetite gneisses (samples DD.4.80 and DD.5.70) generally show weak banding with alternating magnetite-rich and quartz-rich bands. Mineralogically, they are dominated by magnetite, amphibole, quartz and a few crystals of pyroxene (Figure 8(a)). This rock displays a variety of textures: foliated, porphyroblastic and granoblastic textures. Quartz crystals are generally less than $0.1 \mathrm{~mm}$. Pyroxene grains commonly line the foliation.
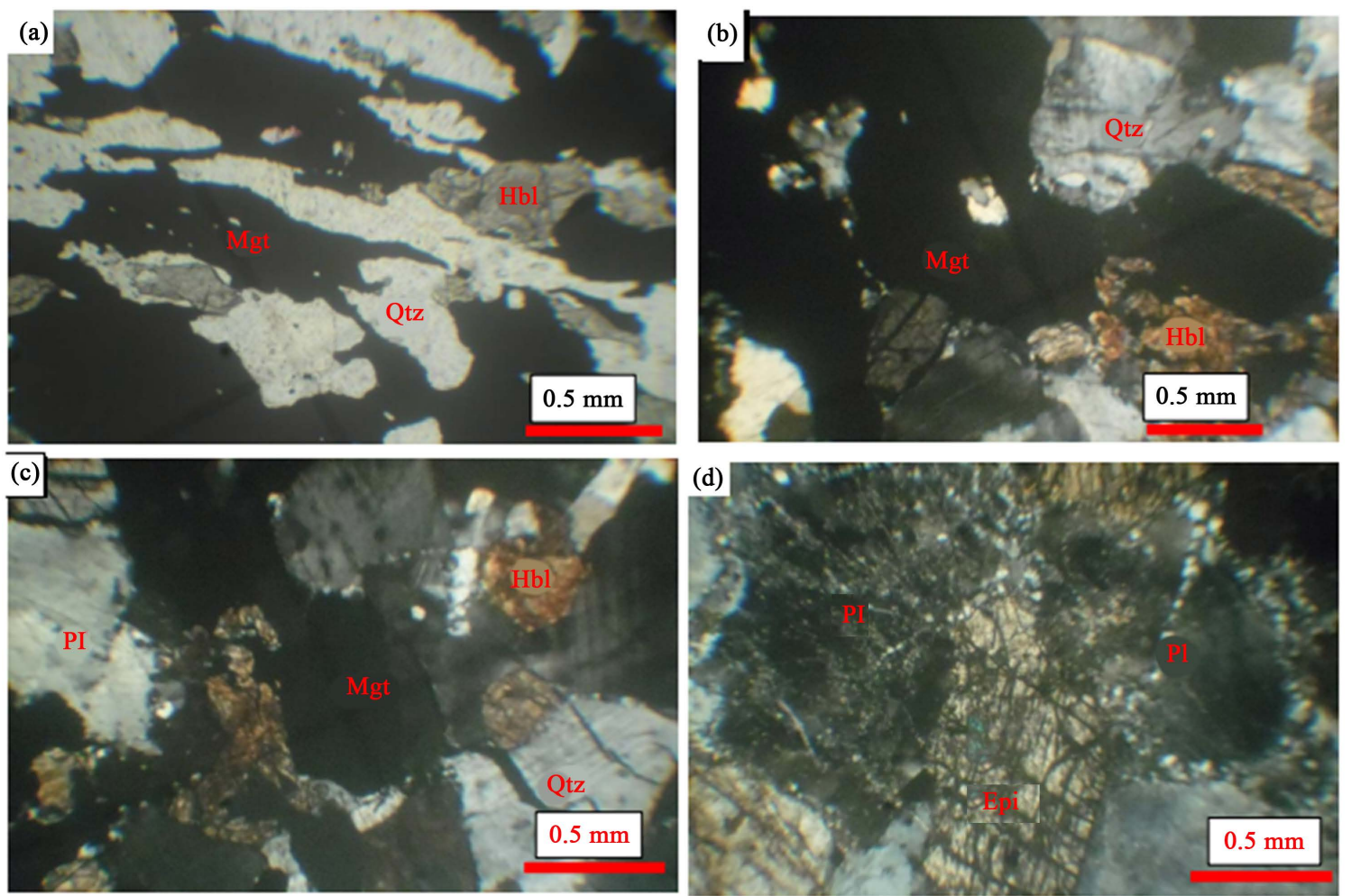

Figure 5. Petrographic features of magnetite gneiss in the Binga iron ore prospect. (a) \& (b) Magnetite stringers associated with hornblende; (c) Fractured quartz crystals filled by magnetite; (d) Altered plagioclase forming a lock-and-key structure with epidote. 

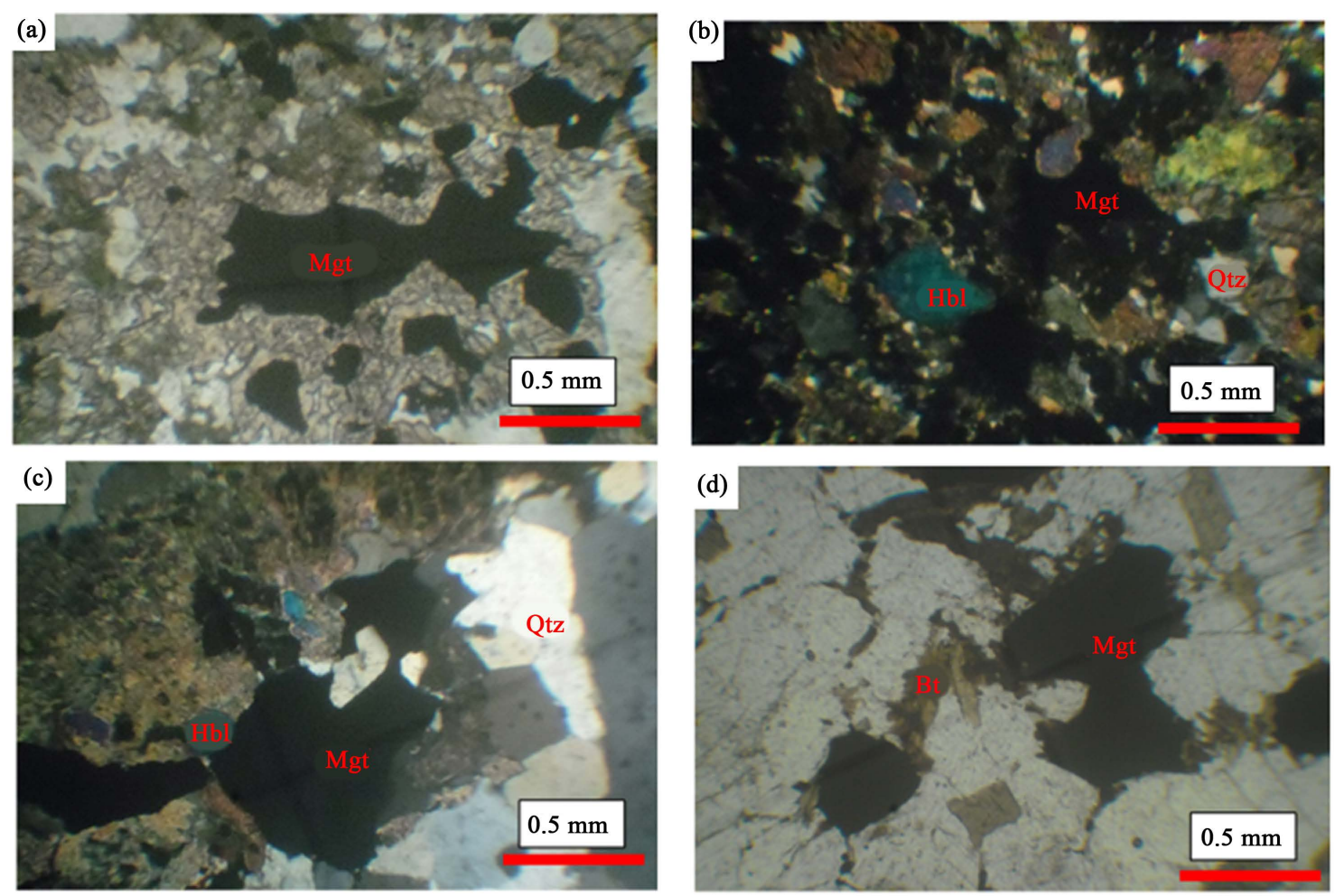

Figure 6. Petrographic features of amphibolite samples from the Binga prospect. (a) Magnetite core with serrated margins enclosed within altered amphibole, and rimmed by later over growths of garnet; (b) \& (c). Lens-shaped hornblende associated with magnetite; (d) Biotite filling fractures and associated with magnetite.
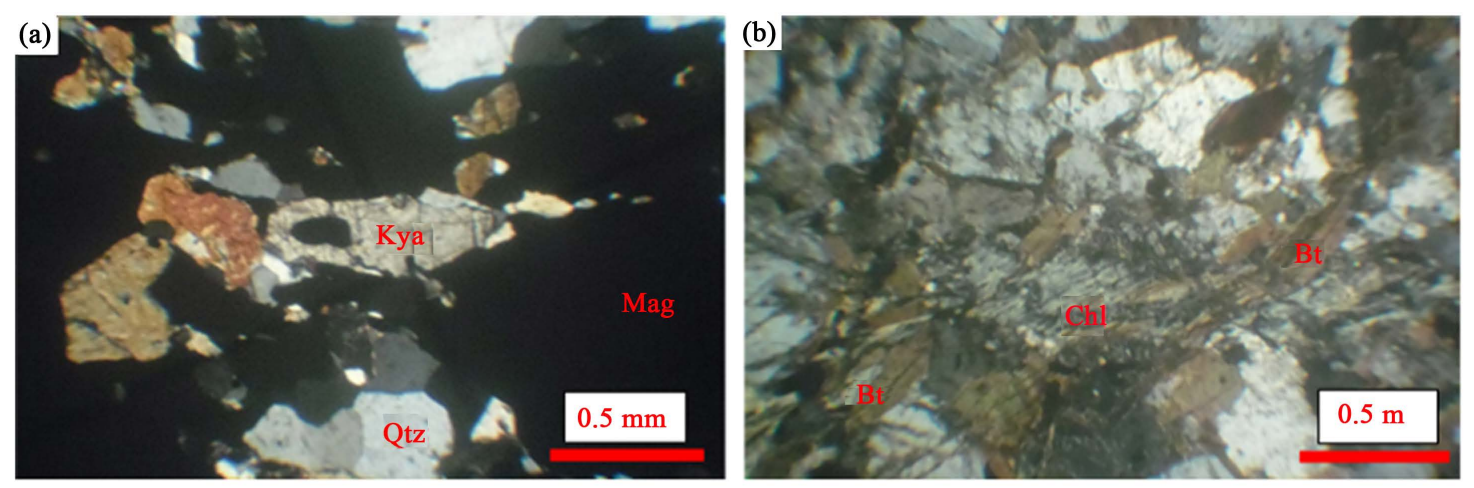

Figure 7. Petrographic features of magnetite gneiss in the Binga prospect. (a) Shows a fractures crystal of Kyanite with magnetite inclusions; (b) Shows green stains, which could have resolved from chlorite alteration of biotite (brown elongated minerals). Kya= Kyanite, Mag = Magnitite, Qtz = Quartz, Bt = Biotite.

The Djadom amphibolitic BIF samples (samples DD.4.70, DD.5.57, DD.20.70, and DD.20.80) are generally strongly foliated with distinct magnetite-rich bands alternating with quartz-dominated bands. The magnetite bands are more conspicuous and continuous (Figure 9(a)) in contrast to those of the magnetite gneiss. Mineralogically, the rock is dominated by magnetite, amphiboles (tremolite and actinolite), quartz (Figure 9(b)) and pyroxene. The quartz grains are elongated to sub-rounded and generally less than $0.1 \mathrm{~mm}$ in size. The rock also displays a variety of textures including foliated and porphyroblastic textures. Magnetite is closely associated with amphiboles (Figure 9(a)) and pyroxenes, possibly resulting from recrystallization of the amphiboles and/ or pyroxene. Magnetite crystals are subhedral to cubic porphyroblasts and range in size from $<0.1 \mathrm{~mm}$ to about $0.5 \mathrm{~m}$. These magnetite crystals also occur as disseminations within garnet and/or pyroxene (Figure 9(d)). Tremolite and actinolite occur mostly in the more altered samples. These minerals define a strong mineral linea- 

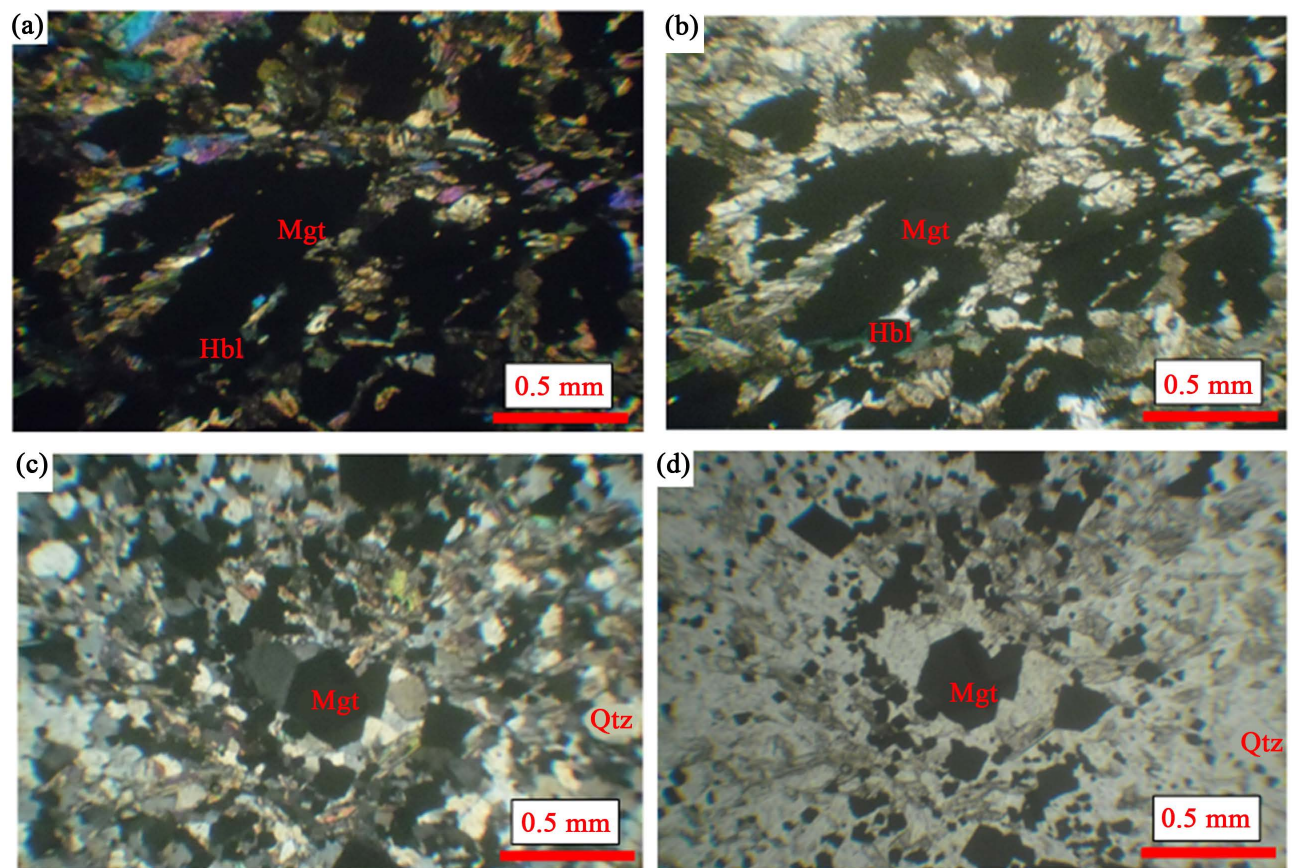

Figure 8: Petrographic features of magnetite gneiss in the Djadom prospect. (a) Anhedral grains of magnetite (black) closely associated with green hornblende; (b) Anhedral grains of magnetite (black) closely associated with green hornblende (observed under cross polars); (c) Abundant euhedral to subhedral crystals with cubic cross sections (porphyroblasts) of magnetite within a nematoblastic quartz-pyroxene dominated matrix (cross polars); (d) Abundant euhedral to subhedral crystals with cubic cross sections (porphyroblasts) of magnetite within a nematoblastic quartz-pyroxene dominated matrix.
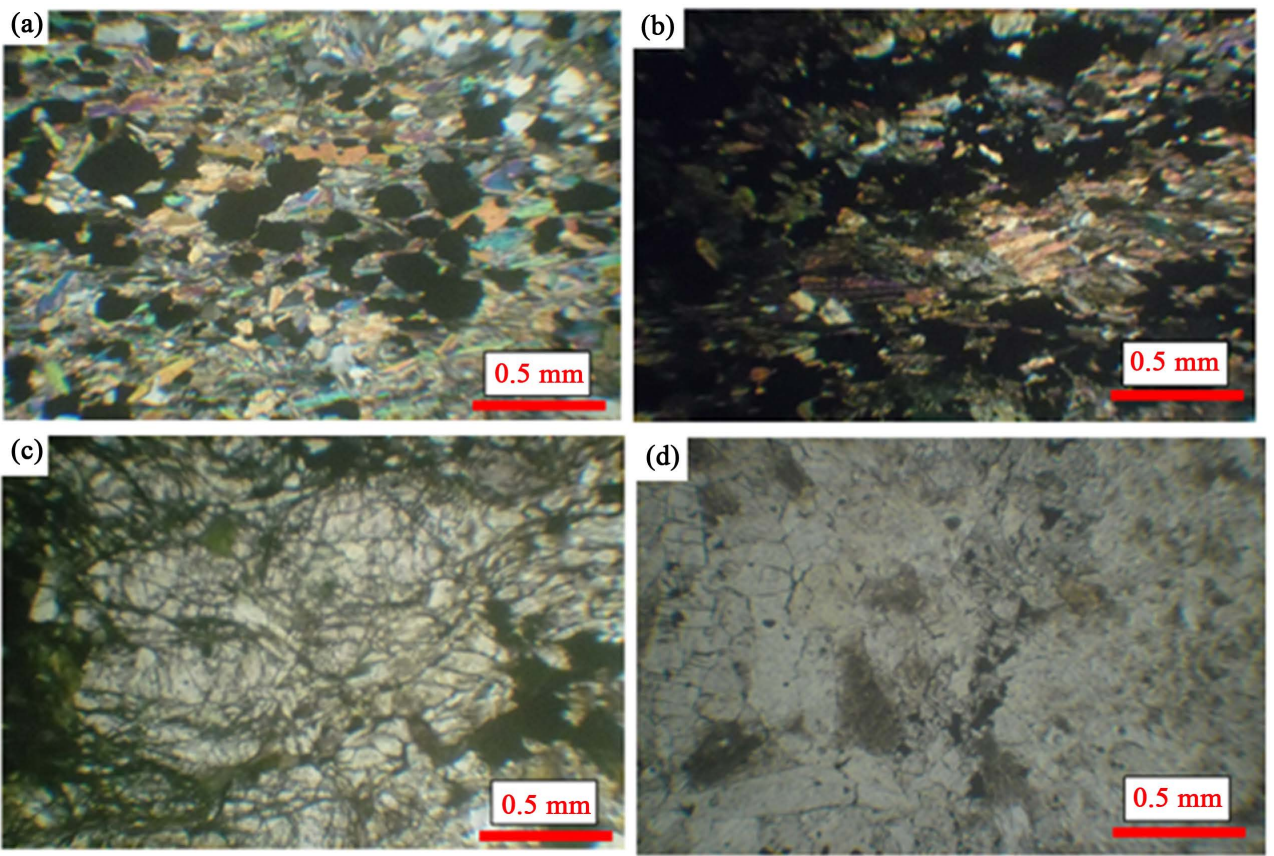

Figure 9. Petrographic features of amphibolitic BIF at Djadom. (a) Anhedral grains of magnetite (black) defining mineral foliation alternating with gangue minerals (mainly quartz, tremolite and actinolite) note the close association of Magnetite with green hornblend; (b) Anhedral grains of magnetite (black) defining mineral foliation and closely associated with green hornblend alternating with gangue minerals (mainly quartz, tremolite and actinolite); (c) Deformed lens-shaped garnet crystals within iron oxide matrix, bounded to the right by magnetite crystals; (d) Anhedral to subhedral crystals of magnetite disseminated within garnet porphyroclast. 
tion sub parallel to the dominant foliation. However the rocks are highly deformed as quartz and garnet appear as lenticular crystals, sometimes occurring within a folded finer-grained matrix.

The fault rocks in the area are represented by samples DD.4.49, DD.5.37, and DD.20.51. These rocks show a clear mylonitic fabric with stains of goethite, and are more deformed than the magnetite gneiss and amphibolitic BIF (Figure 10 and Figure 11). The mineral assemblage is predominantly quartz with little amounts of, magnetite, garnet, and subordinate limonite/goethite.

The samples are generally strongly foliated with well aligned goethite/limonite-rich bands alternating with quartz-dominated bands (Figure 11(a)). Garnet and magnetite occur as deformed lenses or pods (possibly relic porphyroclasts) embedded within a folded, fine-grained matrix of mainly goethite/limonite (Figure 11(b)).

\subsection{Bulk-Rock Geochemistry}

The concentration of major and trace elements for eighteen core samples (nine from Binga and another nine from Djadom) are presented in Table 1 and Table 2, respectively.

Table 1. Major element (wt\%) and trace element (ppm) concentrations of core samples from the Binga iron ore prospect. Samples

\begin{tabular}{|c|c|c|c|c|c|c|c|c|c|}
\hline & BD.8.50 & BD.8.52 & BD.8.54 & BD.9.50 & BD.9.67 & BD.9.86 & BD.13.19 & BD.13.28 & BD.13.38 \\
\hline \multicolumn{10}{|c|}{ Major elements (wt\%) } \\
\hline $\mathrm{SiO}_{2}$ & 48.3 & 49.0 & 46.5 & 52.0 & 55.5 & 44.8 & 46.3 & 54.4 & 55.6 \\
\hline $\mathbf{A l}_{2} \mathbf{O}_{3}$ & 8.1 & 7.6 & 9.7 & 12.5 & 7.5 & 5.8 & 7.4 & 14.5 & 11.3 \\
\hline $\mathrm{Fe}_{2} \mathbf{O}_{3}$ & 32.8 & 30.6 & 32.6 & 21.2 & 29.7 & 40.8 & 33.4 & 17.4 & 22.0 \\
\hline MgO & 3.9 & 4.4 & 4.1 & 4.1 & 2.2 & 3.5 & 4.2 & 4.0 & 2.9 \\
\hline $\mathrm{CaO}$ & 3.8 & 2.4 & 3.1 & 6.3 & 2.6 & 3.1 & 4.6 & 3.5 & 3.6 \\
\hline $\mathrm{Na}_{2} \mathrm{O}$ & 1.9 & 1.6 & 1.2 & 3.5 & 1.8 & 1.30 & 1.7 & 3.7 & 2.7 \\
\hline $\mathbf{K}_{2} \mathbf{O}$ & 0.9 & 1.1 & 1.5 & 1.5 & 1.6 & 0.5 & 0.3 & 1.9 & 1.4 \\
\hline $\mathrm{TiO}_{2}$ & 0.6 & 0.5 & 0.6 & 0.5 & 0.2 & 0.3 & 0.6 & 0.8 & 0.4 \\
\hline MnO & 0.2 & 0.2 & 0.2 & 0.2 & 0.2 & 0.2 & 0.2 & 0.1 & 0.1 \\
\hline LOI & -0.4 & -0.5 & -0.2 & -0.3 & -0.4 & -1.1 & -0.8 & -0.2 & -0.3 \\
\hline Sum & 99.04 & 99.4 & 100.42 & 100.4 & 100.8 & 99.0 & 100.2 & 99.9 & 100.0 \\
\hline \multicolumn{10}{|c|}{ Trace elements (ppm) } \\
\hline As & 10 & 20 & 10 & 10 & 10 & 10 & 10 & 10 & 10 \\
\hline Ba & 630 & 600 & 730 & 820 & 640 & 240 & 360 & 600 & 730 \\
\hline $\mathbf{C l}$ & 220 & 220 & 300 & 190 & 90 & 170 & 90 & 140 & 200 \\
\hline Co & 20 & 10 & 20 & 20 & 20 & 10 & 10 & 40 & 20 \\
\hline $\mathrm{Cr}$ & 111 & 118 & 106 & 57 & 12 & 54 & 136 & 500 & 161 \\
\hline $\mathbf{C u}$ & 170 & 80 & 90 & 30 & 100 & 70 & 40 & 140 & 100 \\
\hline $\mathbf{N i}$ & 60 & 80 & 60 & 30 & 50 & 30 & 40 & 110 & 190 \\
\hline $\mathbf{P}$ & 1020 & 920 & 930 & 800 & 530 & 810 & 1120 & 650 & 890 \\
\hline $\mathbf{P b}$ & 50 & 10 & 10 & 10 & 40 & 10 & 10 & 30 & 10 \\
\hline S & 298 & 237 & 221 & 61 & 184 & 313 & 154 & 321 & 138 \\
\hline Sn & 10 & 10 & 10 & 20 & 30 & 10 & 10 & 20 & 10 \\
\hline $\mathrm{Sr}$ & 410 & 350 & 460 & 640 & 390 & 250 & 410 & 630 & 530 \\
\hline $\mathbf{V}$ & 100 & 60 & 90 & 130 & 50 & 70 & 150 & 250 & 70 \\
\hline $\mathrm{Zn}$ & 140 & 100 & 100 & 80 & 40 & 70 & 100 & 210 & 100 \\
\hline $\mathrm{Zr}$ & 140 & 130 & 150 & 140 & 150 & 70 & 70 & 150 & 200 \\
\hline
\end{tabular}

Footnote 1: magnetite gneiss samples (BD.9.50, BD.9.67, BD.9.86, BD.13.19, BD.13.28, and BD.13.38) and amphibolite samples (BD.8.50, BD.8.52, BD.8.54). 

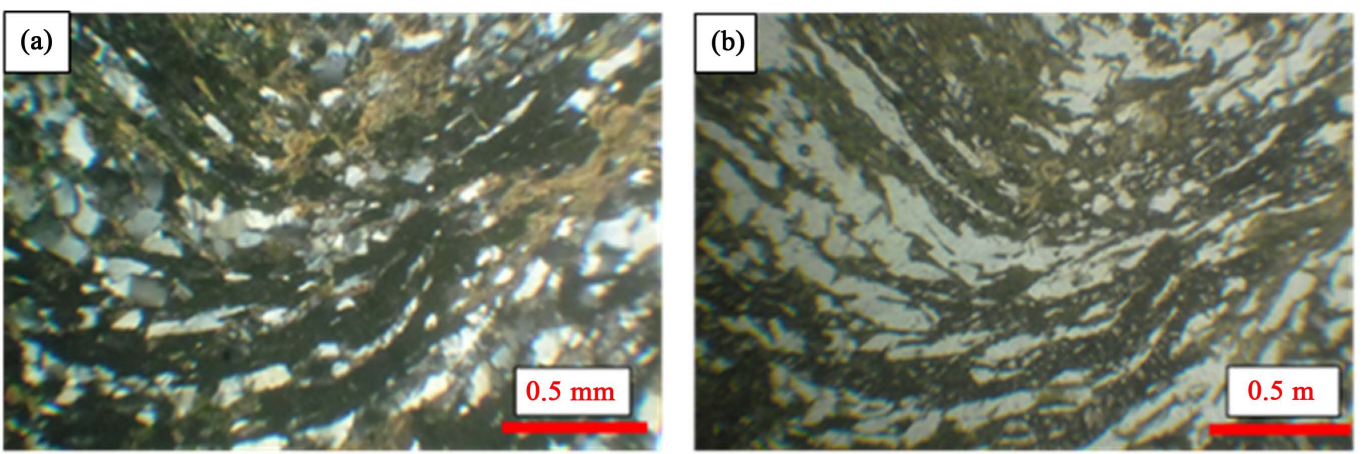

Figure 10. Petrographic features of fault rocks at the Djadom prospect. (a) Foliated alternating bands of iron oxide with quarto-feldsparthic minerals, also showing some micro-folds; (b) Foliated alternating iron oxide with quarto-feldsparthic minerals showing some micro-folds.

Table 2. Major (wt\%) and trace element (ppm) concentrations of core samples from the Djadom iron ore prospect. Samples

\begin{tabular}{|c|c|c|c|c|c|c|c|c|c|}
\hline & DD.4.49 & DD.4.70 & DD.4.80 & DD.5.37 & DD.5.57 & DD.5.70 & DD.20.51 & DD.20.70 & DD.20.80 \\
\hline \multicolumn{10}{|c|}{ Major elements (wt\%) } \\
\hline $\mathrm{SiO}_{2}$ & 45.9 & 49.8 & 47.1 & 56.9 & 49.1 & 51.0 & 66.5 & 45.3 & 42.9 \\
\hline $\mathrm{Al}_{2} \mathbf{O}_{3}$ & 10.2 & 2.9 & 2.8 & 0.3 & 0.1 & 8.0 & 0.1 & 2.1 & 1.8 \\
\hline $\mathrm{Fe}_{2} \mathrm{O}_{3}$ & 33.5 & 37.5 & 43.4 & 37.1 & 47.6 & 27.7 & 28.1 & 48.3 & 51.2 \\
\hline MgO & 3.1 & 2.6 & 2.2 & 0.7 & 4.1 & 4.1 & 0.4 & 3.5 & 3.8 \\
\hline $\mathrm{CaO}$ & 0.7 & 4.8 & 3.1 & 0.6 & 0.9 & 4.3 & 0.5 & 1.0 & 1.0 \\
\hline $\mathrm{Na}_{2} \mathrm{O}$ & 0.0 & 0.2 & 0.5 & 0.0 & 0.0 & 1.6 & 0.0 & 0.1 & 0.1 \\
\hline $\mathrm{K}_{2} \mathrm{O}$ & 0.9 & 0.4 & 0.4 & 0.0 & 0.0 & 0.5 & 0.0 & 0.1 & 0.0 \\
\hline $\mathrm{TiO}_{2}$ & 0.3 & 0.1 & 0.1 & 0.0 & 0.0 & 0.4 & 0.0 & 0.1 & 0.1 \\
\hline MnO & 0.2 & 0.1 & 0.1 & 0.4 & 0.4 & 0.2 & 0.0 & 0.5 & 0.7 \\
\hline LOI & 0.4 & 1.1 & 0.8 & 4.5 & -1.4 & 1.1 & 4.4 & -1.0 & -1.5 \\
\hline Sum & 100.1 & 97.1 & 99.9 & 101.5 & 101.1 & 99.4 & 100.0 & 100.2 & 100.1 \\
\hline \multicolumn{10}{|c|}{ Trace elements (ppm) } \\
\hline As & 10 & 5 & 20 & 10 & 20 & 10 & 5 & 10 & 10 \\
\hline Ba & 70 & 20 & 20 & 5 & 5 & 40 & 5 & 5 & 5 \\
\hline $\mathbf{C l}$ & 280 & 200 & 190 & 10 & 250 & 150 & 10 & 50 & 110 \\
\hline Co & 5 & 5 & 5 & 5 & 10 & 20 & 5 & 5 & 10 \\
\hline $\mathrm{Cr}$ & 174 & 180 & 173 & 239 & 231 & 248 & 176 & 20 & 16 \\
\hline $\mathbf{C u}$ & 30 & 20 & 30 & 40 & 20 & 80 & 20 & 20 & 40 \\
\hline $\mathbf{N}$ & 20 & 10 & 20 & 20 & 20 & 40 & 10 & 5 & 5 \\
\hline $\mathbf{P}$ & 710 & 630 & 690 & 580 & 700 & 450 & 650 & 770 & 800 \\
\hline $\mathbf{P b}$ & 5 & 5 & 20 & 20 & 40 & 5 & 20 & 60 & 50 \\
\hline $\mathrm{S}$ & 873 & 172 & 695 & 779 & 72 & 105 & 84 & 18 & 495 \\
\hline Sn & 5 & 5 & 5 & 5 & 5 & 5 & 5 & 10 & 20 \\
\hline $\mathrm{Sr}$ & 5 & 40 & 30 & 30 & 30 & 70 & 110 & 100 & 100 \\
\hline $\mathbf{V}$ & 50 & 20 & 20 & 5 & 5 & 100 & 10 & 20 & 10 \\
\hline $\mathrm{Zn}$ & 60 & 20 & 40 & 30 & 20 & 40 & 30 & 40 & 50 \\
\hline $\mathrm{Zr}$ & 100 & 50 & 40 & 40 & 60 & 70 & 240 & 180 & 180 \\
\hline
\end{tabular}

Footnote 2: magnetite gneiss (samples DD.4.80 and DD.5.70), amphibolitic BIF (samples DD.4.70, DD.5.57, DD.20.70, and DD.20.80), fault rocks (sample DD.4.49, DD.5.37, DD.20.51). 

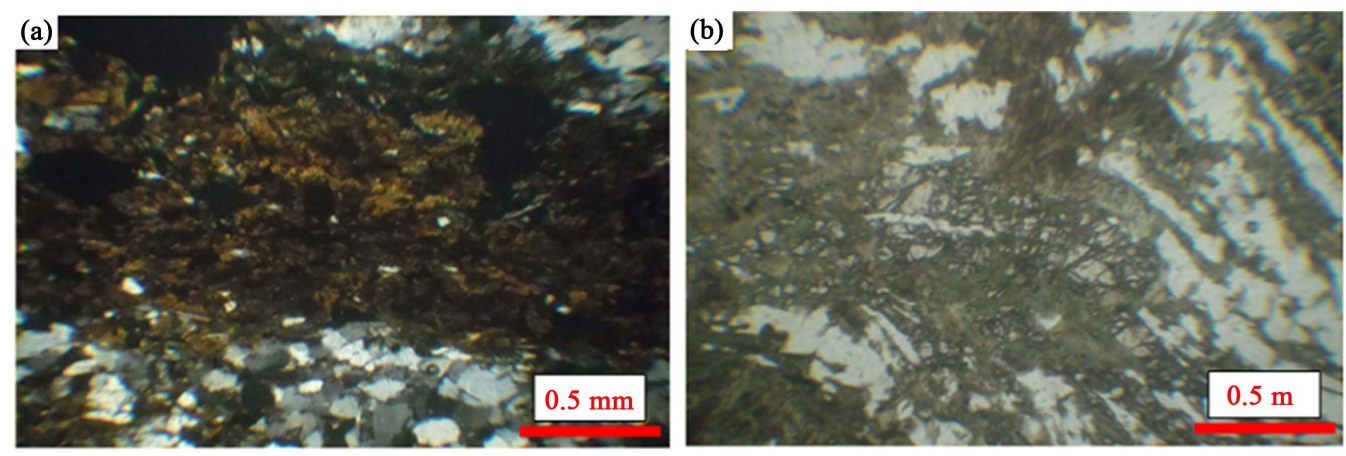

Figure 11. Petrographic features of fault rocks at the Djadom prospect. (a) Deformed lenticular grains of magnetite (black) within massive iron oxide matrix (brown); (b) Lens-shaped crystal of garnet (light pink) within a foliated matrix of alternating iron oxide (light brown) and quartz (white).

\subsubsection{Binga Iron Ore Prospect}

The chemistry of the magnetite gneiss (Table 1) shows a high $\mathrm{Fe}_{2} \mathrm{O}_{3}$ content (17.44 - 33.40 wt\%), with a slightly higher value for sample BD.9.86 which has an $\mathrm{Fe}_{2} \mathrm{O}_{3}$ content of $40.87 \mathrm{wt} \%$, while the amphibolite shows $\mathrm{Fe}_{2} \mathrm{O}_{3}$ values in the range of (30.62 - $32.80 \mathrm{wt} \%$ ). $\mathrm{SiO}_{2}$ concentration (46.50 - $49.00 \mathrm{wt} \%$ ) is slightly lower in the amphibolite compared to its concentration (44.80 - $55.60 \mathrm{wt} \%$ ) in the magnetite gneiss. Aluminium oxide content is low (7.61 - $9.71 \mathrm{wt} \%$ and 7.45 - $14.55 \mathrm{wt} \%$ ) in both the amphibolite and the magnetite gneiss, respectively. Both the magnetite gneiss and the amphibolite are also characterized by a low $\mathrm{TiO}_{2}$ content $(0.16$ $0.8 \mathrm{wt} \%$ and $0.55-0.57 \mathrm{wt} \%$, respectively).

\subsubsection{Djadom Iron Ore Prospect}

The chemistry of the magnetite gneiss (Table 2) shows a slightly higher $\mathrm{Fe}_{2} \mathrm{O}_{3}$ content (27.73 - 43.39 wt\%), than that of the fault rocks $\mathrm{Fe}_{2} \mathrm{O}_{3}$ content (37.12 - $33.56 \mathrm{wt} \%$ ), while that of the amphibolitic BIF (major oxides, Table 4.2) shows a slightly higher $\mathrm{Fe}_{2} \mathrm{O}_{3}$ content (37.45 - $51.23 \mathrm{wt} \%$ ). $\mathrm{SiO}_{2}$ concentration is low for the magnetite gneiss (47.1 - $51 \mathrm{wt} \%$ ) and fault rocks (45.9 - $56.9 \mathrm{wt} \%$ ), but slightly lower in the amphibolitic BIF (42.9 $49.8 \mathrm{wt} \%)$. The $\mathrm{Al}_{2} \mathrm{O}_{3}$ content in the amphibolitic $\mathrm{BIF}(0.09-2.89 \mathrm{wt} \%)$ is low as compared to the magnetite gneiss (2.8 - $8.03 \mathrm{wt} \%)$ and fault rocks (0.29 - $10.2 \mathrm{wt} \%)$. The magnetite gneiss, amphibolitic BIF and fault rocks are characterized by low $\mathrm{TiO}_{2}$ content.

In both prospects, trace element concentrations (Table 1 and Table 2) show high contents of $\mathrm{Ba}, \mathrm{Zn}, \mathrm{Cu}$ and $\mathrm{V}$ but lower abundances of Sr and Zr.

\subsubsection{Binary Plots for Major Elements and Some Selected Trace Elements for the Binga and Djadom Iron Ore Prospects}

In depicting the relationship between the various major oxides and trace elements in the Binga and Djadom iron ore prospects, binary plots were done for major oxides and some selected trace elements. In an attempt to understand these trends, geochemical data for two known magmatic-related iron ore occurrences (Akom II, Cameroon) and (Bergslagen, Sweden) were incorporated and plotted alongside those from the Binga and Djadom iron ore prospects. The results are presented in Figures 12-14. Figures 12(a)-(h) shows binary plots for $\mathrm{Fe}_{2} \mathrm{O}_{3}$ versus other major oxides $\left(\mathrm{SiO}_{2}, \mathrm{TiO}_{2}, \mathrm{Al}_{2} \mathrm{O}_{3}, \mathrm{MgO}, \mathrm{CaO}, \mathrm{Na}_{2} \mathrm{O}, \mathrm{K}_{2} \mathrm{O}\right.$, and $\left.\mathrm{MnO}\right)$, while Figures $13\left(\mathrm{a}_{1}\right)-\left(\mathrm{h}_{1}\right)$ shows binary plots of $\mathrm{Fe}_{2} \mathrm{O}_{3}$ versus trace elements (Ba, Cr, Ni, Sr, Zr, V, Cu, and Co) for Binga, Djadom and Akom II, and (A to $\mathrm{H})$ for Bergslagen.

Figure 4.10 shows binary plots for some selected major elements $\left(\mathrm{K}_{2} \mathrm{O}, \mathrm{Al}_{2} \mathrm{O}_{3}, \mathrm{TiO}_{2}\right.$ and $\left.\mathrm{MgO}\right)$ and selected trace elements (Ba, Ni, Sr, and $\mathrm{Zr}$ ) for Binga, Djadom, Akom II and Bergslagen.

In both the Binga and Djadom prospects $\mathrm{SiO}_{2}$ decreases with increasing $\mathrm{Fe}_{2} \mathrm{O}_{3}$ (Figure 12(a)). The same pattern is observed for $\mathrm{Al}_{2} \mathrm{O}_{3}$, and $\mathrm{Na}_{2} \mathrm{O}$ (Figure 12(c) and Figure 12(f) respectively). This suggests that the iron enrichment process requires progressive loss of silicon and aluminium.

In both the Binga and Djadom prospects $\mathrm{Ba}, \mathrm{Co}, \mathrm{Cr}, \mathrm{Cu}$, and $\mathrm{Ni}$ are negatively correlated with $\mathrm{Fe}_{2} \mathrm{O}_{3}$ (Figure 13( $\left.a_{1}\right)$, Figure 13( $\left.b_{1}\right)$, Figure 13( $\left.c_{1}\right)$, Figure 13( $\left(g_{1}\right)$, Figure 13 $\left(h_{1}\right)$ ).

$\mathrm{Sr}$ and $\mathrm{Zr}$ show a strong negative correlation with $\mathrm{Fe}_{2} \mathrm{O}_{3}$ in the Binga prospect, while in the Djadom prospect $\mathrm{Sr}$ and $\mathrm{Zr}$ show a weak positive correlation with $\mathrm{Fe}_{2} \mathrm{O}_{3}$ (Figure 13( $\left.\mathrm{d}_{1}\right)$ \& Figure 13( $\left.\mathrm{e}_{1}\right)$ ). 


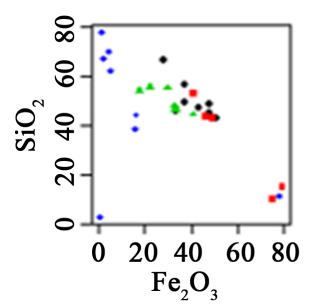

(a)

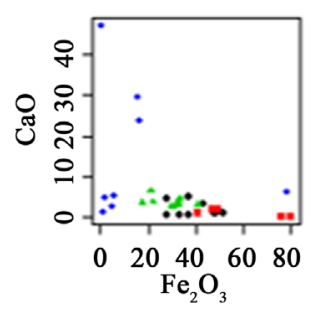

(e)

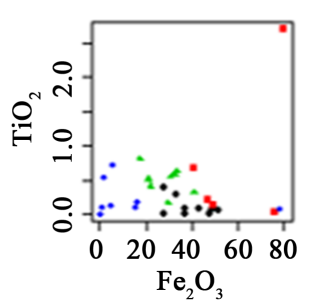

(b)

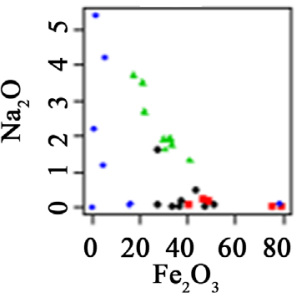

(f)

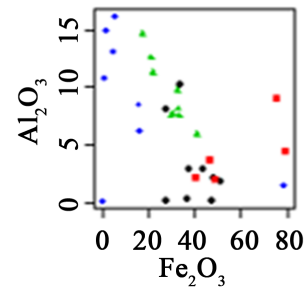

(c)

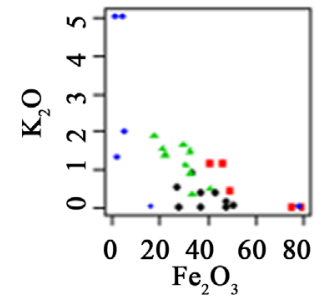

(g)

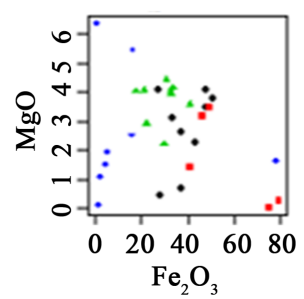

(d)

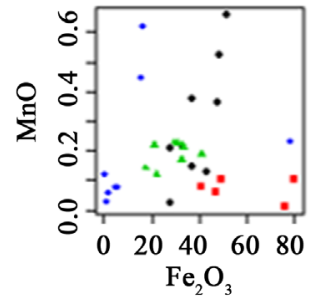

LEGEND

- Akom II

- Diadom Prospect

A Binga Prospect

- Bergslagen

Figure 12. Binary plots of Fe2O3 versus other major oxides $\left(\mathrm{SiO}_{2}, \mathrm{TiO}_{2}, \mathrm{Al}_{2} \mathrm{O}_{3}, \mathrm{MgO}, \mathrm{CaO}, \mathrm{Na}_{2} \mathrm{O}, \mathrm{K}_{2} \mathrm{O}\right.$, and $\left.\mathrm{MnO}\right)$ for Binga, Djadom plotted alongside (Akom II, Cameroon and Bergslagen, Sweden).
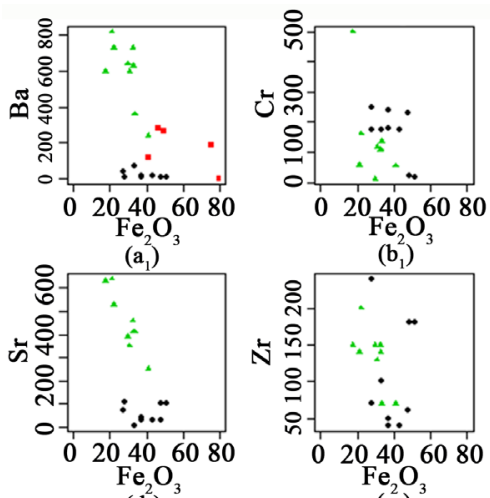

$\left(\mathrm{b}_{1}^{2}\right)$

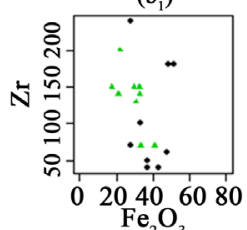

$\left(\mathrm{e}_{1}\right)$

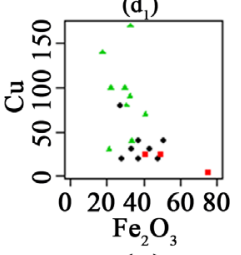

$\left(\mathrm{g}_{1}\right)$

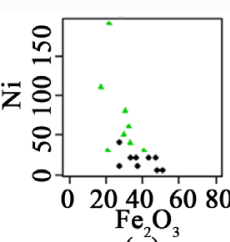

$\left(\mathbf{c}_{1}\right)$

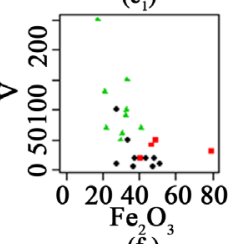

$\left(\mathrm{f}_{1}\right)^{3}$
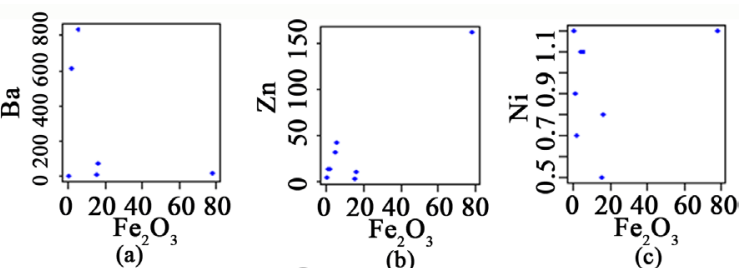

(b)

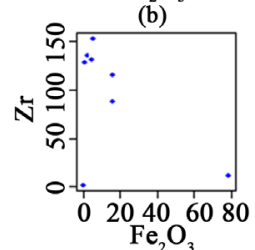

(e)

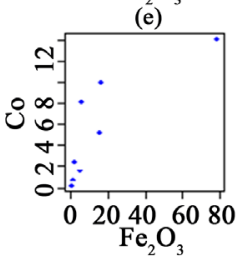

(h)

Figure 13. Binary plots of $\mathrm{Fe}_{2} \mathrm{O}_{3}$ versus trace elements; $\mathrm{Ba}, \mathrm{Cr}, \mathrm{Ni}, \mathrm{Sr}, \mathrm{Zr}, \mathrm{V}, \mathrm{Cu}$, and Co for Binga, Djadom plotted alongside other skarn (Akom II, Cameroon and Bergslagen, Sweden).

In the Binga iron ore prospect, binary plots for large ion lithophile (LIL) elements $\mathrm{Ba}$ and $\mathrm{Sr}$ together with $\mathrm{K}_{2} \mathrm{O}$ and $\mathrm{Al}_{2} \mathrm{O}_{3}$ display a strong linear co-variation with zirconium (Figure 14( $\left.\mathrm{a}_{1}\right)$, Figure 14( $\left.\mathrm{c}_{1}\right)$, Figure 14( $\left.\mathrm{d}_{1}\right)$ \& Figure 14( $\left.\mathrm{e}_{1}\right)$ ), whilst in the Djadom iron ore prospect, plots of $\mathrm{Ba}$ and $\mathrm{K}_{2} \mathrm{O}$ with the exception of $\mathrm{Sr}$ do not show any linear trend with $\mathrm{Zr}$ (Figure 14( $\left.\mathrm{a}_{1}\right)$, Figure 14( $\left.\mathrm{c}_{1}\right)$, Figure 14( $\left.\mathrm{d}_{1}\right)$ \& Figure 14( $\left.\mathrm{e}_{1}\right)$ ).

\section{Interpretations and Discussions}

\subsection{Petrographic Interpretations}

\subsubsection{Petrographic Interpretations of the Binga Iron Ore Prospect}

Most samples within the Binga prospect show a close association of magnetite with amphibole and pyroxene. This suggests that amphiboles and/or pyroxenes in these samples are often replaced (either partially or com- 


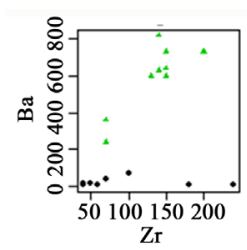

(a)

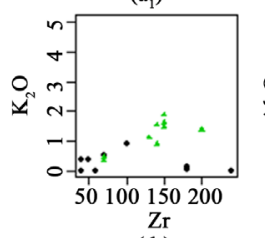

$\left(d_{1}\right)$

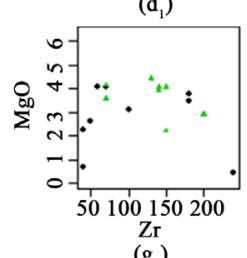

$\left(\mathrm{g}_{1}\right)$

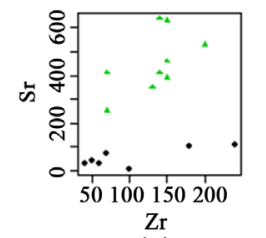

(c)

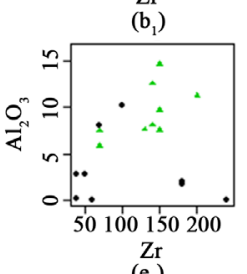

$\left(\mathrm{e}_{1}\right)$

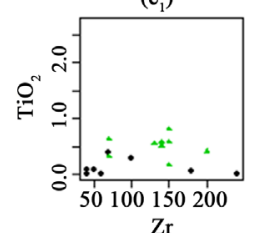

$\mathrm{Zr}$
$\left(\mathrm{f}_{1}\right)$

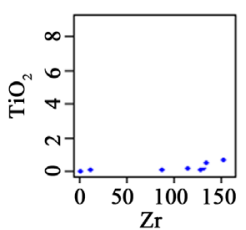

(a)

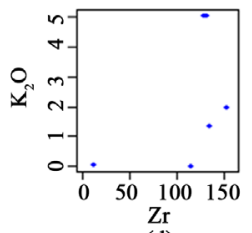

(d)

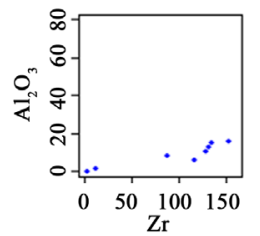

(b)

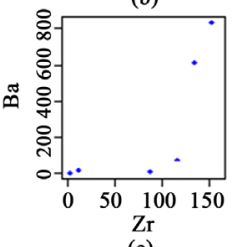

(e)

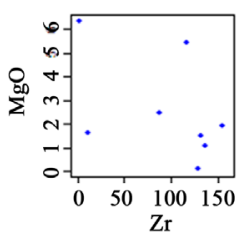

(c)

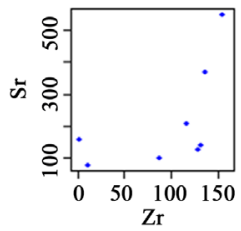

(f)

LEGEND

- Diadom Prospect

- Binga Prospect

- Bergslagen

Figure 14. Bivariate plots for selected major elements $\left(\mathrm{K}_{2} \mathrm{O}, \mathrm{Al}_{2} \mathrm{O}_{3}, \mathrm{TiO}_{2}\right.$ and $\left.\mathrm{MgO}\right)$ and selected trace elements (Ba, Ni, Sr, and $\mathrm{Zr}$ ) for Djadom, Binga, and Bergslagen (NB: the Djadom and Binga prospects are plotted using the same scale, while Bergslagen is drawn using a different scale. This is due to the difference in geochemical values. Akom II is not plotted because the suit of elements used here were not reported for Akom II).

pletely) by magnetite. Replacement of amphiboles/pyroxenes by magnetite may be hydrothermal and/or metamorphic in origin. The Binga amphibolites show some chlorite alteration (Figure 4.3(B)), which might have resulted from chloritisation of biotite and/or hornblende. This could suggest retrograde metamorphism although kyanite, which is characteristic of middle amphibolite facies at a temperature of $\sim 600^{\circ} \mathrm{C}$ appears in the mode of some samples (Figure 7(a)).

Rocks in the Binga prospect possibly underwent an intensive high-temperature recrystallization which gave rise to small new grains of hornblende, plagioclase, and pyroxene, all of which are rimmed by late garnet overgrowths.

Furthermore, metamorphic overprint in these rocks is represented by rims of biotite around oxides, and rims of secondary amphibole around primary amphibole and pyroxene (Figure 6(b)).

\subsubsection{Petrographic Interpretations of the Djadom Iron Ore Prospect}

Most of the samples from Djadom show fine-scale banding and strong foliations defined by magnetite and quartzo-feldspathic minerals (Figure 9(a) and Figure 9(b)), occasionally with increasing amounts of actinolite, tremolite, and chlorite within the light-green bands. This scenario is similar to that of the Hainan Province, south China, and could have resulted from late-stage hydrothermal alteration as reported by [16]. Other samples show discontinuous, probably relict banding of magnetite within fine-grained quartz dominated matrix. Alteration halos are also present, which could be as a result of hydrothermal overprint (Figure 8(c) \& Figure 8(d)).

In the altered samples, leucocratic bands and magnetite crystals are crosscut by micro-fractures, while microfolds are occasionally observed. The highly altered samples show deformed porphyroclasts of garnet crystals that have survived ductile deformation lying within a fine-grained iron oxide matrix.

The different habits of magnetite from anhedral to euhedral could suggest a metamorphic or hydrothermal origin. Samples with cubic megacrystals suggest that magnetite occurs here as a result of hydrothermal overprint and this is strongly supported by foliated texture presented by the fault rocks (Figure 10(a) and Figure 10(b)). Magnetite is closely associated with amphiboles, garnets and pyroxenes, occurring either as disseminated inclusions, along micro-fractures and/or grain boundaries of these minerals. This suggests that amphiboles, garnets and pyroxenes in these samples are often replaced (either partially or completely) by medium- to coarse-grained magnetite.

Replacement of amphiboles, garnets/pyroxenes by magnetite may be hydrothermal and/or metmorphic in origin. 


$$
\begin{gathered}
2 \mathrm{KFe}_{3} \mathrm{AlSi}_{3} \mathrm{O}_{10}(\mathrm{OH})_{2}+\mathrm{O}_{2} \rightarrow \underset{\mathrm{KAlSi}_{3} \mathrm{O}_{8}}{2}+2 \mathrm{Fe}_{3} \mathrm{O}_{4}+2 \mathrm{H}_{2} \mathrm{O} \\
\text { Biotite (annite) } \\
\text { K-feldspar } \quad \text { Magnetite }
\end{gathered}
$$

At low and medium grade conditions, garnet is much stronger than quartz and feldspar and does not deform when isolated in a quartzo-feldspathic matrix. At higher temperatures, the difference in strength decreases to an extent that all three minerals can deform together [17]-[19]. Highly deformed samples show elongated lensshaped garnets that have been folded and emplaced parallel to the deformation fabric (Figure 9(c)) and occur along with deformed quartz crystals (Figure 11(a)).

The sigmoidal shape of the garnet porphyroclasts attest to deformation, and suggests that differential stresses were high around the rims of these porphyroclasts, probably leading to dynamic recrystallization forming a coreand-mantle structure.

The amphibolitic BIF's at the Djadom iron ore prospect are interbedded with magnetite-amphibole-pyroxene bearing gneisses, and are similar to amphibolitic itabirite as defined by [20], as the former consist of bands dominated mainly by two types of amphiboles (tremolite and actinolite) alternating with bands of iron oxides. The texture and mineralogy of these amphibolitic BIF's is similar to those reported for amphibolitic itabirite by [16] for the Hainan Province in south China, as well [21] for the Cauê Formation in Quadrilátero Ferrífero, Minas Gerais, Brazil.

\subsection{Geochemical Interpretations for the Binga and Djadom Iron Ore Prospects}

Considering that all the amphibolites associated with BIF belong to the same genetic type then those elements which are incompatible in basaltic systems [22] should display systematic variations in a suite of cogenetic samples. Disruption of these correlations will occur if the elements are mobile. Zirconium is a good indicator of fractionation and it is relatively immobile during both seawater alteration of basalt and subsequent amphibolite facies metamorphism [23]-[25]. Consequently $\mathrm{Zr}$ has been employed in this study to evaluate fractionation trends. Any suite of rocks that has been subjected to hydrothermal alteration and metamorphism is likely to experience element remobilization. Trace element mobility is controlled by the mineralogical changes which take place during alteration and the nature of the fluid phase.

As a generalization, incompatible elements belonging to the LIL ( $\mathrm{Sr}, \mathrm{K}$, and $\mathrm{Ba}$ ) group are mobile, whereas High Field Strength (HFS) elements are immobile [23]. At the Binga iron ore prospect, plots of $\mathrm{K}_{2} \mathrm{O}$, Ba and $\mathrm{Sr}$ display a strong linear co-variation with Zr. This reflects a primary igneous process [22]. Whilst at the Djadom iron ore prospect, plots of LIL elements (K and $\mathrm{Ba}$ ) with the exception of Sr do not show any linear co-variation with Zr. This could suggest that the LIL elements have at some stage been mobilized to different degrees, thus pointing out to metamorphism and or hydrothermal alteration.

[23]; [24]; and [26], demonstrated that Ti, $\mathrm{P}$ and $\mathrm{Zr}$ tend to be immobile during metamorphism and alteration. In addition to these, $\mathrm{Al}_{2} \mathrm{O}_{3}$ and $\mathrm{MgO}$ are stable under conditions of hydrothermal, sea water weathering and up to mid amphibolite facies metamorphism. Thus a combination of the former and the later are more reliable for petrogenetic interpretations, and can be used to discriminate between different tectonic environments.

At the Binga iron ore prospect, $\mathrm{TiO}_{2}$ displays a linear co-variation with $\mathrm{Zr}$, and $\mathrm{Al}_{2} \mathrm{O}_{3}$ displays a strong linear co-variation with $\mathrm{Zr}$. This is supported by [27], where a moderately coherent pattern for $\mathrm{Al}_{2} \mathrm{O}_{3} / \mathrm{TiO}_{2}$ was reported for the Bergslagen skarn-related deposit. Also, the negative correlation between $\mathrm{Sr}$ and $\mathrm{Zr}$ (lithophile elements) with $\mathrm{Fe}_{2} \mathrm{O}_{3}$ (a siderophile) (Figure 4.9) at the Binga prospect, depicts a magmatic related process and could also attest to the fact that the ore enrichment process might not have been related to any metamorphic or hydrothermal event which could have remobilised the elements in the system.

Whilst in the Djadom prospect, $\mathrm{TiO}_{2}, \mathrm{Al}_{2} \mathrm{O}_{3}$ and $\mathrm{MgO}$ display a negative co-variation with $\mathrm{Zr}$. This could suggest that the rock suits at the Djadom iron ore prospect were overprinted by metamorphism, likely involving some hydrothermal fluids. This statement is supported by [27], as they reported non-coherent plots for $\mathrm{Zr} / \mathrm{TiO}_{2}$ and $\mathrm{Zr} / \mathrm{Al}_{2} \mathrm{O}_{3}$, and explained that the scattered data could reflect mobility of HFSE during alteration. Reference [28], demonstrated that $\mathrm{Al}_{2} \mathrm{O}_{3}$ and $\mathrm{MgO}$ are mobile during green schist metamorphism, thus also attesting to the fact that the remobilization of magnesium and aluminium could reflect a metamorphic event, which probably led to the enrichment of the protore. The latter is strongly supported by the positive correlation of Sr and $\mathrm{Zr}$ with $\mathrm{Fe}_{2} \mathrm{O}_{3}$ (Figure 13). 


\subsection{Ore Forming Processes and Overprint Effects}

The results of this study suggest that the Binga iron ore prospect could be contemporaneous with magmatic intrusions, as most features of this prospect show evidence of magmatic fluid activity. This is however in line with studies carried out by several authors such as; [9] [29] [30] which show multiple deformation events within the Ntem Complex. These deformation events might have led to the development of fractures, faults and shear zones thus enabling magma to be intruded.

Most of the samples from Djadom show foliated and granoblastic textures, which are characteristic of metamorphic rocks. Three metamorphic events are postulated; a high grade metamorphic event (which led to the development of garnets) followed by dynamo-metamorphism, which is represented by mylonitic and ductile deformation (Figure 9(c), Figure 10(a) and Figure 10(b), and Figure 11(a) and Figure 11(b)) restricted mainly to the iron-rich bands, then retrograde metamorphism (evidenced by chloritization as well as recrystallization and over growths of garnet) possibly within the amphibolite facies.

The depletion of LIL elements ( $\mathrm{K}$ and $\mathrm{Ba}$ ) coupled with the negative correlation between $\mathrm{Al}$, Mg and HFS elements with $\mathrm{Zr}$ could suggest metamorphic over print on the Djadom prospect, which was accompanied by hydrothermal fluids. This is in line with studies carried out by [13].

Hydrothermal alteration could have been the most significant process contributing iron ore enrichment in this prospect, as evidence by the presence of; garnet, tremolite, actinolite, biotite, feldspar, quartz, and iron oxide (Figures 9(a)-(d)). Structurally, this is evidence by discontinuous pinch-and-swell boudinages and irregular folds in amphibolitic BIF's and Fe-rich fault rocks, (Figure 9(c), Figure 10(a) and Figure 10(b) and Figure 11(a) and Figure 11(b) respectively). This is similar to structures described by [16], as they used such structures to show the presence of hydrothermal alteration within the Hainan Province of south China.

The Djadom iron ore prospect lies in the Ayena Series. Very little is known about this series. This area must have probably experienced complex deformation and metamorphism resulting in the development of folds, micro-fractures and possibly shear zones. The magnetite ore at Djadom is structurally-controlled and attest to the role of deformation and, possibly, hydrothermal alteration in the ore-forming process.

\section{Conclusions}

Several iron ore occurrences have been discovered in the Precambrian Belt of southern Cameroon, but much is not known about the Binga and Djadom iron ore occurrences. These iron ore occurrences are described here for the first time, and represent probably skarn-related deposits, as their nature and complexity are similar to those of other skarn-related deposits, as emphasized by several workers [31] [32].

The Binga iron ore prospect probably represents an intrusive related iron skarn deposit which is associated with a shear zone and magmatism.

The genesis of the Djadom iron ore prospect is possibly tied to both skarn formation and hydrothermal enrichment.

By analysing for Rare Earth Elements (REE's) and comparing their patterns to those of other known iron ore deposits in the world, new fingerprints could be developed, which could be taken into consideration during subsequent exploration activities in the different prospects.

\section{Acknowledgements}

This article is a part of the MSc. thesis of G. N. N, at the University of Buea under the supervision of C. E. S. This work is greatly supported by West African Minerals (represented by CMC in Cameroon), and G. N. N thanks the management of CMC especially Mr. Anton Mauve, Mr. Steve Makang and Mr. Duncan Bowker for their kind support and consideration.

\section{References}

[1] Suh, C.E., Cabral, A.R., Shemang, E.M., Mbinkar, L. and Mboudou, G.G.M. (2008) Two Contrasting Iron Deposits in the Precambrian Mineral Belt of Cameroon, West Africa. Exploration and Mining Geology, 17, 197-207. http://dx.doi.org/10.2113/gsemg.17.3-4.197

[2] Rosière, C.A. and Chemale Jr., F. (2000) Brazilian Iron Formations and their Geological Setting. Revista Brasileira de Geociências, 30, 274-278. 
[3] United Nations Development Programme (1987) Recherches minières dans le sud-est du Cameroun (Project No.: DP/ UN/CMR-81-005/2): Final Technical Report, 89.

[4] Castaing, C., Ouédraogo, F., Abessolo, A., Ngueya, P., Colson, J. and Selouane, K. (2011) Stratégie de développement du Secteur Géologique et minier au cameroun. Rapport D’etape Provisoire, Sofreco 21-22.

[5] Achoundong, G. (2007) Vegetation. In: Houstin, N. and Seignobos, C., Eds., Atlas of Cameroon, Les Éditions Jeune Afrique, Paris, 64-65.

[6] Tsaléfac, M. (2007) Climate. In: Houstin, N. and Seignobos, C., Eds., Atlas of Cameroon, Les Éditions Jeune Afrique, Paris, 62-63.

[7] Tchameni, R., Lerouge, C., Penaye, J., Cocherie, A., Milesi, J.P., Toteu, S.F. and Nsifa, N.E. (2000) Mineralogical Constraint for Metamorphic Conditions in a Shear Zone Affecting the Archean Ngoulemakong Tonalite, Congo Craton (Southern Cameroon) and Retentivity of U-Pb SHRIMP Zircon Dates. Journal of African Earth Sciences, 58, 67-80. http://dx.doi.org/10.1016/j.jafrearsci.2010.01.009

[8] Toteu, S.F., Penaye, J. and Poudjom Djomani, Y. (2004) Geodynamic Evolution of the Pan-African Belt of Central Africa with Special Reference to Cameroon. Canadian Journal of Earth Sciences, 41, 73-85. http://dx.doi.org/10.1139/e03-079

[9] Lasserre, M. and Soba, D. (1976) Age libérien des granodiorites et des gneiss à pyroxènes du Cameroun méridional. Bulletin du BRGM, 2, 17-32.

[10] Feybesse, J.L., Johan, V., Maurizot, P. and Bessolo, A. (1986) Evolution tectonométamorphique libérienne et éburnéenne de la partie NW du craton zaïrois (SW Cameroun). In: Matheis, G. and Schandelmeier, H., Eds., Current Research in African Earth Science, Balkema, Rotterdam, 9-12.

[11] Penaye, J., Toteu, S.F., Tchameni, R., Van Schmus, W.R., Tchakounte, J., Ganwa, A., Miyem, D. and Nsifa, E.N. (2004) The 2.1 Ga West Central African Belt in Cameroon: Extension and Evolution. Journal of African Earth Sciences, 39, 159-164. http://dx.doi.org/10.1016/j.jafrearsci.2004.07.053

[12] Maurizot, P., Abessolo, A., Feybesse, J.L. and Johan, L.P. (1986) Etude de prospection minière du Sud-Ouest Cameroun Synthèse des travaux de 1978 à 1985. Rapport de BRGM, 85, 274.

[13] Toteu, S.F., Van Schmus, W.R., Penaye, J. and Nyobé, J.B. (1994) U-Pb and Sm-Nd Evidence for Eburnean and PanAfrican High-Grade Metamorphism in Cratonic Rocks of Southern Cameroon. Precambrian Research, 67, 321-347. http://dx.doi.org/10.1016/0301-9268(94)90014-0

[14] Lerouge, C., Cocherie, A., Toteu, F.S., Penaye, J., Milési, J.P., Tchameni, R., Nsifa, E.N., Fanning, C.M. and Deloule, E. (2006) SHRIMP U-Pb Zircon Age Evidence for Paleoproterozoic Sedimentation and 2.05 Ga Syntectonic Plutonism in the Nyong Group, South-Western Cameroon: Consequences for the Eburnean-Transamazonian Belt of NE Brazil and Central Africa. Journal of African Earth Sciences, 44, 413-427. http://dx.doi.org/10.1016/j.jafrearsci.2005.11.010

[15] www.alsglobal.com

[16] Xu, D.R., Wang, Z.L., Cai, J.X., Wu, C.J., Bakun-Czubarow, N., Wang, L., Chen, H.Y., Baker, M.J. and Kusiak, M.A. (2013) Geological Characteristics and Metallogenesis of the Shilu Fe-Ore Deposit in Hainan Province, South China. Ore Geology Reviews, 53, 318-342. http://dx.doi.org/10.1016/j.oregeorev.2013.01.015

[17] Ji, S. and Martignole, J. (1996) Ductility of Garnet as an Indicator of Extremely High Temperature Deformation: Reply. Journal of Structural Geology, 18, 1375-1379. http://dx.doi.org/10.1016/S0191-8141(96)00065-X

[18] Den Brok, S.W.J. and Kruhl, J.H. (1996) Ductility of Garnet as an Indicator of Extremely High Temperature Deformation: Discussion. Journal of Structural Geology, 18, 1369-1373. http://dx.doi.org/10.1016/S0191-8141(96)00064-8

[19] Kleinschrodt, R. and McGrew, A.J. (2000) Garnet Plasticity in the Lower Continental Crust: Implications for Deformation Mechanisms Based on Microstructures and SEM Electron Channeling Pattern Analysis. Journal of Structural Geology, 22, 795-809. http://dx.doi.org/10.1016/S0191-8141(00)00010-9

[20] Rosière, C.A., Chemale Jr., F. and Guimarães, M.L.V. (1993) Um modelo para a evoluc, ão microestrutural dos minérios de ferro do Quadrilátero Ferrífero. Parte I—estruturas e recristalizac,ão. Geonomos, 1, 65-84.

[21] Spier, C.A., de Oliveira, S.M.B. and Rosière, C.A., (2003) Geology and Geochemistry of the Águas Claras Quadrilátero Ferrífero, Minas Gerais, Brazil. Miner. Deposita, 38, 751-774. http://dx.doi.org/10.1007/s00126-003-0371-2

[22] Wood, D.A., Tarney, J. and Weaver, B.L. (1981) Trace Element Variations in Atlantic Ocean Basalts and Proterozoic Dykes from Northwest Scotland: their Bearing upon the Nature and Geochemical Evolution of the Upper Mantle. Tectonophysics, 75, 91-112. http://dx.doi.org/10.1016/0040-1951(81)90211-0

[23] Peace, J.A. and Cann, J.R. (1973) Tectonic Setting of Basic Volcanic Rocks Determined Using Trace Element Analysis. Earth and Planetary Science Letters, 19, 290-300. http://dx.doi.org/10.1016/0012-821X(73)90129-5

[24] Floyd, P.A and Winchester, J.A. (1975) Magma Type and Tectonic Setting Discrimination Using Immobile Elements. Earth and Planetary Science Letters, 27, 211-218. http://dx.doi.org/10.1016/0012-821X(75)90031-X 
[25] Weaver, B.L., Tarney, J. and Windley, B. (1981) Geochemistry and Petrogenesis of the Fiskenaesset Anorthite Complex Southern West Greenland: Nature of the Parent Magma. Geochimica et Cosmochimica Acta, 45, 711-725. http://dx.doi.org/10.1016/0016-7037(81)90044-2

[26] Shevais, J.W. (1982) Ti-V Plots and Petrogenesis of Modern and Ophiolitic Lavas. Earth and Planetary Science Letters, 59, 101-118. http://dx.doi.org/10.1016/0012-821X(82)90120-0

[27] Jansson, N.F. and Allen, R.L. (2013) Timing and Setting of Skarn and Iron Oxide Formation at the Smältarmossen Calcic Iron Skarn Deposit, Bergslagen, Sweden. Mineralium Deposita, 48, 313-339. http://dx.doi.org/10.1007/s00126-012-0432-5

[28] Peace, J.A. (1976) Statistical Analysis of Major Element Patterns in Basalts. Journal of Petrology, 17, 15-45. http://dx.doi.org/10.1093/petrology/17.1.15

[29] Cahen, L., Snelling, N.J., Delhal, J. and Vail, J.R. (1984) The Geochronology and Evolution of Africa. Clarendon Press, Oxford, 512.

[30] Feybesse, J.L., Johan, V., Triboulet, C., Guerrot, C., Mayaga-Mikolo, F., Bouchot, V. and Eko N’dong, J. (1986) The West Central African Belt: A Model of 2.5 - 2.0 Ga Accretion and Two-Phase Orogenic Evolution. Precambrian Research, 87, 161-216. http://dx.doi.org/10.1016/S0301-9268(97)00053-3

[31] Smirnov, V.I. (1976) Geology of Mineral Deposits. MIR, Moscow, 520.

[32] Meinert, L.D., Dipple and Nicolescu, G.M. (2005) World Skarn Deposits. In: Hedenquist, J.W., Thompson, J.F.H., Goldfarb, R.J. and Richards, J.P., Eds., Economic Geology 100th Anniversary Volume 1905-2005, Elsevier Science B.V., Amsterdam, Volume 1905-2005, 299-336. 